\title{
Comparison study on potential syngas produced by mild thermoconversion of microalgal residues through proton nuclear magnetic resonance and thermogravimetric analysis-fourier transform infrared spectroscopy
}

\author{
Shuangfei $\mathrm{Li}^{1} \cdot$ Liangxu Liu $^{1}$ - Jay Jiayang Cheng ${ }^{2} \cdot$ Xuewei Yang ${ }^{1}$
}

Received: 10 September 2019 / Revised: 22 December 2019 / Accepted: 26 December 2019 / Published online: 16 January 2020

(C) The Author(s) 2020

\begin{abstract}
This paper presented a mechanism study of syngas production through lipid-extracted microalgal residues by investigating how the structure of these residues affected the pyrolysis characteristics. The results showed that both Chlorella sorokiniana 21 and Monoraphidium $3 \mathrm{~s} 35$ residues could be pyrolyzed efficiently at low temperatures from 120 to $380^{\circ} \mathrm{C}$, with a final residue of less than $22.75 \%$. Hemicellulose with carboxyl groups was the main component of both microalgal residues, most likely contributing to the production of the $\mathrm{C}=\mathrm{O}$ compounds and carbon monoxide $(\mathrm{CO})$. A large amount of $\mathrm{CHO}, \mathrm{CH}_{2} \mathrm{O}$, and $\mathrm{CH}_{3} \mathrm{O}(60.09 \%$ in total) was observed from C. sorokiniana 21, which was 1.58 times more than that from Monoraphidium 3s 35 . Pyrolysis of the C. sorokiniana 21 residue yielded more $\mathrm{C}=\mathrm{O}$ and $\mathrm{CH}_{\mathrm{n}}$ compounds with less activation energy $\left(52.97-58.57 \mathrm{~kJ} \mathrm{~mol}^{-1}\right)$ and a higher reaction rate $\left(0.105 \% \mathrm{~s} \mathrm{~s}^{-1}\right)$ than that of Monoraphidium 3s35. The different pyrolysis characteristics between the two microalgal residues might be attributed to structural variations.
\end{abstract}

Keywords Microalgal residue $\cdot$ Structure $\cdot$ Pyrolysis $\cdot$ Thermogravimetric characteristics

\section{Introduction}

Biomass has been considered one of the most promising renewable energy sources in the world. Compared with fossil fuels, biomass can be processed into liquid transportation fuels, which can substantially decrease the net emissions of carbon into the atmosphere [1]. Biomass can be obtained from land crops as well as ocean habitats. Microalgae, known as sunlight-driven cell factories, can convert carbon dioxide to potential biofuel materials [2] and are an important source of biomass, with the merits of high yields and a short life cycle $[3]$.

Xuewei Yang

yangxw@szu.edu.cn

1 Shenzhen Key Laboratory of Marine Biological Resources and Ecology Environment, Shenzhen Key Laboratory of Microbial Genetic Engineering, College of Life Sciences and Oceanography, Shenzhen University, Shenzhen 518055, People's Republic of China

2 Department of Biological and Agricultural Engineering, North Carolina State University, Raleigh, NC 27695, USA
There have been major challenges in biochemically converting lignocellulosic biomass into biofuel due to the complex structure of the biomass and the difficulty of separating its components in an economically feasible way [4]. Pyrolysis, however, has provided an alternative solution for converting cellulosic biomass into renewable energy and valuable chemicals [5]. In the last decade, intensive pyrolysis research has been performed on lignocellulosic biomass, ranging from agricultural residues such as corn stover and wheat straw to energy crops such as switchgrass [6]. Forestry wastes such as wood bark have also been the targets for pyrolysis [5]. Research on microalgal biomass pyrolysis using Py-GC/MS and DAEM [7] has been reported. Thermal degradation of the microalgae Chlorella vulgaris ESP-31, Nannochloropsis oceanica CY2, and Chlamydomonas sp. JSC4 has also been analyzed [8]. Recently, microalgae have mainly been used for lipid and biodiesel production [9]. The reutilization of residues after the biofuel conversion process is significant for increasing the economic efficiency of microalgae. However, the mechanism of pyrolysis for lipid-extracted microalgal residues has barely been reported. The online combination of thermogravimetric analysis (TGA) and fourier transform 
infrared (FTIR) spectroscopy has been successfully applied to the study of the evolution of volatile products with time in the thermal pyrolysis of polymers [10] as well as Nannochloropsis sp. [11]. It is important to understand the mechanism of microalgal residue pyrolysis, the thermogravimetric decomposition of the volatile products, and the influence of the composition and structure of the microalgae on the pyrolysis kinetics.

In this study, lipid-extracted residues of the microalgae Chlorella sorokiniana and Monoraphidium were investigated with TGA/FTIR to elucidate their dynamic pyrolysis behavior including kinetics and volatile products produced. Furthermore, the chemical structures of the two microalgal residues were analyzed with proton nuclear magnetic resonance ( $\left({ }^{1} \mathrm{H}\right.$ NMR) spectroscopy to determine the influence of the structural variation on the pyrolysis.

\section{Materials and methods}

\subsection{Microalgal residue preparation}

The microalgal strains Chlorella sorokiniana 21 and Monoraphidium 3s35 used in this study were collected from the coastal waters of Shenzhen, Guangdong Province, China. Blue-green medium (BG-11) with $1.5 \%$ agar supplement was used to maintain the strains [12]. Each individual cultivation test was carried out with 3 replicates for 10 days. Slots on an incubation shaker platform (Constant Temperature Breeding Shaker, MOMA, Shanghai, China) were randomly assigned. To initiate the cultivation, $80 \mathrm{~mL}$ of axenic culture in the exponential phase (dry cell mass density $50 \pm 0.08 \mathrm{mg} \mathrm{L}^{-1}$ ) was inoculated into $1 \mathrm{~L}$ flasks with $800 \mathrm{~mL}$ of sterile BG-11 medium. The flasks were covered with autoclavable foam and cultivated at a room temperature of $26{ }^{\circ} \mathrm{C}$ with an initial $\mathrm{pH}$ of 7.1. Three rows of cool white portable fluorescent light tubes (PMRGT8-30 W, Mei Optoelectronics Technology Company, Foshan, Guangdong Province, China) were used with a light intensity of $100.5 \mu \mathrm{mol} \mathrm{m} \mathrm{m}^{-2} \pm 2.0 \mathrm{SE}$. Aeration of $0.25-0.75 \mathrm{~L}$ air per minute was applied to each cultivation flask. To collect the microalgal biomass, the cultures were centrifuged (Centrifuge 5810R, Eppendorf, Germany) at $4000 \times g$ for $20 \mathrm{~min}$ and resuspended in distilled water. After repeating the above process 3 times, the microalgal biomass was freeze-dried (FreeZone 2.5, LABCONCO, USA) for 3 days. A Soxhlet extractor was used for lipid extraction from the previously obtained microalgal biomass, with $1.5 \mathrm{~g}$ extracted with chloroform/methanol $(1 / 2, \mathrm{v} / \mathrm{v})$ at $75{ }^{\circ} \mathrm{C}$ for $12 \mathrm{~h}$. After lipid extraction, the microalgal residues were then dried at $30{ }^{\circ} \mathrm{C}$ under vacuum for $12 \mathrm{~h}$. Three biological replicates for each sample of the microalgae biomass residue were prepared for further experiments.

\subsection{Microalgal residue composition analysis}

Microalgal residue composition analysis was performed through the method of the Association of Official Analytical Chemists (AOAC) (1984) [13], which has also been used for analyzing the composition of marine algae Enteromorpha spp. [14], Schizochytrium sp. [15], Spirulina algae [16], and the microalga Porphyridium cruentum [17]. Dried algal samples were analyzed for neutral detergent fiber (NDF) [18], acid detergent fiber (ADF) [19], acid detergent lignin (ADL) [20], and ash in ADL according to the procedures of Van Soest et al. (1991) and AOAC (1984) [13]. Hemicellulose, cellulose, and Klason lignin contents were determined by the differences between ADF and NDF content, ADF and ADL content, and ADL and ash content, respectively [21]. Three biological and measurement replicates were performed throughout this study.

\subsection{Algal biomass structure analysis with ${ }^{1} \mathrm{H}$ NMR spectroscopy}

${ }^{1} \mathrm{H}$ NMR spectra of microalgal residues were obtained by a Bruker 500 Ultrashield I100605 400-MHz spectrometer outfitted with a $5-\mathrm{mm}$ broadband probe (Borosilicate Glass Company, China). Firstly, $20 \mathrm{mg}$ of microalgal residue was dissolved in $1 \mathrm{~mL}$ of DMSO- $d_{6}$ (dimethyl sulfoxide-d6), filtered with a $0.45-\mu \mathrm{m}$ PTFE (poly tetra fluoroethylene) filter to remove any suspended particulates, and then loaded into 5mm diameter NMR tubes [22]. Three measurement replicates were performed throughout this study.

\subsection{Thermogravimetric analysis with TG-FTIR (thermogravimetric analysis coupled with fourier transform infrared analysis)}

The thermogravimetric characteristics of the microalgal residues were determined by thermogravimetry coupled with Fourier transform infrared (TG-FTIR) analysis (STA449 F3, Naichi Instrument Company, China; TENSOR27 FTIR, Bruker, Germany). High-purity $\mathrm{N}_{2}$ was used as the protective gas at a flow rate of $20 \mathrm{~cm}^{3} \mathrm{~min}^{-1}$. Approximately $10 \mathrm{mg}$ of microalgal residue was heated from 25 to $650{ }^{\circ} \mathrm{C}$ at $10{ }^{\circ} \mathrm{C} \mathrm{min}^{-1}$ and then held for $1 \mathrm{~h}$ at the highest temperature. The volatiles released during pyrolysis of the microalgae were detected online with a Bruker FTIR Tensor Spectrometer (TENSOR27 FTIR, Bruker, Germany). FTIR spectra were recorded from 400 to $4000 \mathrm{~cm}^{-1}$. Before the microalgal samples were processed in the system, a blank test was carried out first to eliminate the buoyancy effect. Three measurement replicates were performed throughout this study. 


\subsection{Microalgae pyrolysis kinetics}

The Arrhenius equation used in previously reported work was employed to describe the pyrolysis reaction rate in this study as follows [7]:

$\frac{d X}{d t}=-A e^{-\left(\frac{E}{R T}\right)} X^{n}$

where the notation of the Arrhenius equation $X$ (Eq. (1)) was defined as the extent of the pyrolysis reaction. The conversion value $X$ was determined as $\left(w-w_{f}\right) /\left(w_{0}-w_{f}\right), t$ is the time of reaction, $A$ is the pre-exponential or frequency factor, $E$ is the activation energy, $R$ is the universal gas constant, $T$ is the absolute temperature, and $n$ is the order of reaction. The linearized form of the Arrhenius equation was used to determine the kinetic constants $A, E$, and $n$. The simplified form of the linearized Arrhenius equation is as follows:

$\ln \left(\frac{-1}{w_{0}-w_{f}} \frac{d w}{d t}\right)=1 n A^{-}\left(\frac{E}{R T}\right)+n \ln \left(\frac{w-w_{f}}{w_{0}-w_{f}}\right)$

where $w_{0}$ is the initial weight at the beginning of the pyrolysis, $w_{\mathrm{f}}$ is the final weight at the end of each stage of the pyrolysis (details are explained in a later section), and $w$ is the weight at any time of the pyrolysis process.

Eq. (2) can be written in linear form [7]:

$y=B+C x+D z$

where $y, x, z, B, C$, and $D$ (Eq. (3)) are defined as follows (Eqs. (4)-(6)):

$y=\ln \left(\frac{-1}{w_{0}-w_{f}} \frac{d w}{d t}\right)$

$x=\frac{1}{R T}$

$z=\ln \left(\frac{w-w_{f}}{w_{0}-w_{f}}\right)$

$B=\ln A$

$C=-\frac{E}{R}$

$D=n(9)$

The constants $B, C$, and $D$ were estimated with multilinear regression of the TGA data for each stage using Microsoft Excel (Microsoft, Seattle, USA). The kinetic parameters (A, $E$, and $n$ ) were determined according to Eqs. (7), (8), and (9). Three measurement replicates were performed throughout this study.

The data were analyzed with Statistical Package of the Social Sciences (SPSS) software (Windows version 7.0, SPSS, Inc., Chicago, IL). Paired $t$ test was used to analyze continuous data. A $p$ value $<0.05$ was considered significant.

\section{Results and discussion}

\subsection{Chemical composition and structure of $C$. sorokiniana 21 and Monoraphidium 3s35 residues}

The chemical compositions of the microalgal residues of C. sorokiniana 21 and Monoraphidium 3s35 are presented in Table 1. As shown in the table, hemicellulose was the major component (over $40 \%$ dry-weight basis) of both microalgal residues. This finding is consistent with the chemical composition research on the marine algae Enteromorpha spp., in which the dominant component of the cellular wall is hemicellulose [23]. Cellulose and lignin were observed as the minor components in both microalgae (less than 3\%). Previous research has reported that the polysaccharides of sea algae can be divided into cell wall polysaccharides such as cellulose and hemicellulose [24]. Lignin-like compounds and lignin were also discovered in the cell wall of the red alga Calliarthron cheilosporioides and Coleochaete algae [25]. Statistical analysis indicated that there was no significant difference in the composition between the two microalgal residues [26].

To assess differences in the chemical structure of C. sorokiniana 21 and Monoraphidium 3s35, we acquired ${ }^{1} \mathrm{H}$ NMR spectra to compare the functional group differences, as shown in Fig. 1 and Table 2. Both microalgal residues contained more than $13 \%$ alkanes based on the integrated peaks of $\mathrm{CH}_{3}$ and $\mathrm{CH}_{2}$ (0-1.6 ppm). Notably, C. sorokiniana 21 contains a large amount of $\mathrm{CHO}, \mathrm{CH}_{2} \mathrm{O}$, and $\mathrm{CH}_{3} \mathrm{O}(60.09 \%$ in total), which is 1.58 times more than that in Monoraphidium 3s35 (only 38.12\%). In addition, the functional groups of $\mathrm{ArOH}, \mathrm{HC}=\mathrm{C}$ (nonconjugated), and $\mathrm{CHO}$ accounted for $31.51 \%$ in Monoraphidium 3s35, which is 4.81 times more than that in C. sorokiniana 21 (6.55\%).

Overall, although there is no significant difference between the compositions of these two microalgae, structural variation was observed: C. sorokiniana 21 contained more $\mathrm{CHO}$,

Table 1 Chemical composition of microalgl residue Chlorella sorokiniana 21 and Monoraphidium 3s35. Data are shown as mean \pm standard deviation $(n=3)$

Composition (\% dry based) Sample

Monoraphidium 3s35 C. sorokiniana 21

\begin{tabular}{lcc}
\hline $\mathrm{NDF}^{\mathrm{a}}$ & $45.98 \pm 0.79$ & $47.11 \pm 1.74$ \\
$\mathrm{ADF}^{\mathrm{b}}$ & $4.43 \pm 0.35$ & $4.73 \pm 0.44$ \\
Cellulose & $2.82 \pm 0.11$ & $2.70 \pm 0.59$ \\
Hemicellulose & $41.56 \pm 1.13$ & $42.38 \pm 2.12$ \\
Lignin & $2.42 \pm 0.04$ & $2.64 \pm 0.53$ \\
\hline
\end{tabular}

${ }^{\mathrm{a}} N D F$ :neutral detergent fiber

${ }^{\mathrm{b}} A D F$ acid detergent fiber 
Fig. 1 Proton nuclear magnetic resonance $\left({ }^{1} \mathrm{H}\right.$ NMR $)$ spectra of microalgal residue. a Chlorella sorokiniana $21 . \mathbf{b}$

Monoraphidium 3s35

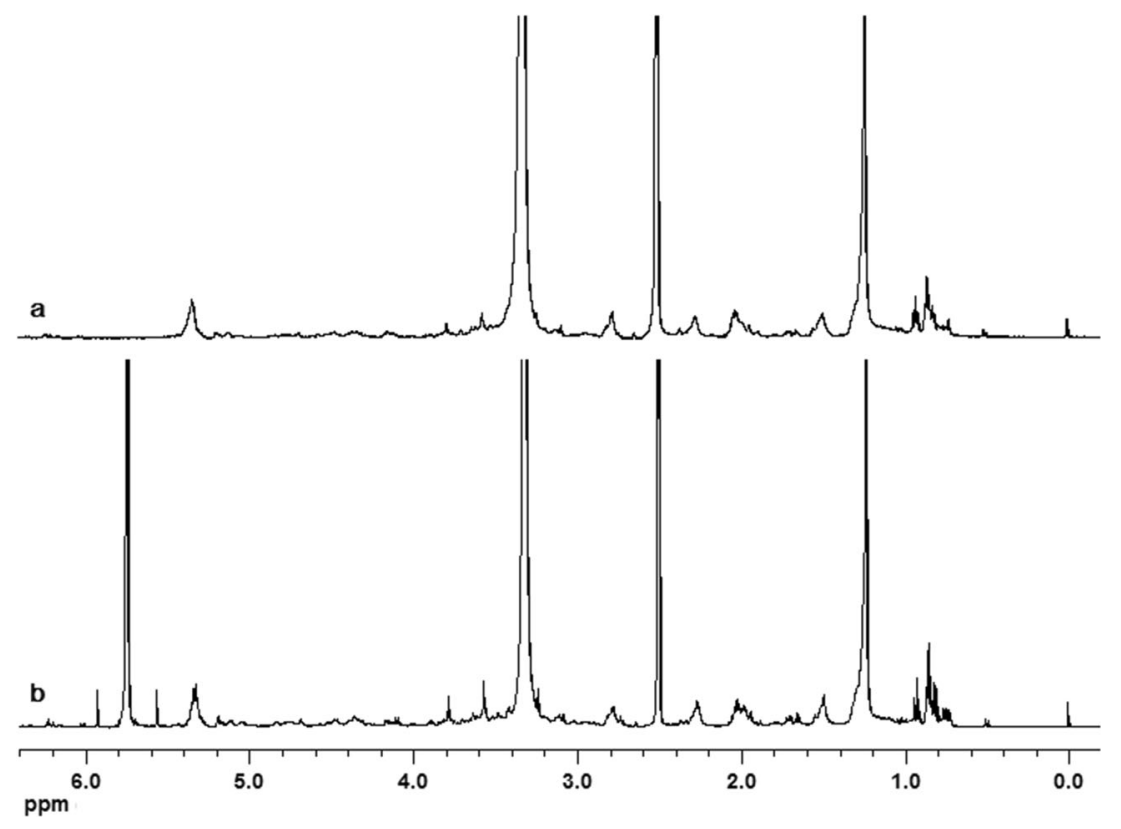

$\mathrm{CH}_{2} \mathrm{O}$, and $\mathrm{CH}_{3} \mathrm{O}$ groups, and Monoraphidium $3 \mathrm{~s} 35$ contained more $\mathrm{ArOH}$ and $\mathrm{HC}=\mathrm{C}$ groups. It was reported that there are two different kinds of structures in cellulose: crystalline and amorphous domains. Depending on both source and history, cellulose consists of these crystalline and amorphous domains in varying proportions [27]. The presence of amorphous cellulose was indicated by strong $\mathrm{C}-\mathrm{H}$ stretching vibrations, and the C-O-C stretching vibrations attributed to $\alpha$-(14)-glycosidic linkages were designated as an "amorphous" absorption band, indicating an intensity increase in the amorphous cellulose. The different chemical compositions of cellulose could lead to various thermal decomposition results.

\subsection{Pyrolysis of $C$. sorokiniana 21 and Monoraphidium 3 s35 residues}

\subsubsection{Thermogravimetric characteristics}

Thermogravimetric analysis Figure 2 shows the thermogravimetry (TG) and derivative thermogravimetry
(DTG) results of the microalgal residues of $C$. sorokiniana 21 and Monoraphidium 3s35 in the pyrolysis process. Both microalgal residues had three distinct weight loss stages during thermal degradation: dehydration, active pyrolysis, and passive pyrolysis, with temperature ranges of $25-120^{\circ} \mathrm{C}$, $120-500^{\circ} \mathrm{C}$, and $500-650^{\circ} \mathrm{C}$, respectively. The active pyrolysis stage contained two substages, which was different from the pyrolysis of plant lignocellulosic biomass such as corn stover [28]. The active pyrolysis temperature for hemicelluloses is usually from 190 to $360{ }^{\circ} \mathrm{C}$, so the appearance of active pyrolysis substage $1\left(120\right.$ to $\left.380{ }^{\circ} \mathrm{C}\right)$ is likely attributed to the large amount of hemicelluloses in the microalgal residue. The TG results also revealed that the final residue yields of the microalgal residue $(22.20 \%$ for C. sorokiniana 21 and $22.75 \%$ for Monoraphidium $3 \mathrm{~s} 35)$ were significantly lower than those of plant lignocellulosic biomass, such as corn stover (33.32\%) [29] and rice straw $(29.5 \%)$ [30]. This result indicated that the thermal decomposition of microalgal residue can be more efficient than that of lignocellulosic biomass.
Table $2{ }^{1} \mathrm{H}$ NMR (proton nuclear magnetic resonance) spectral distribution analysis of functional groups present in the microalgal residues based on integrated peak areas assigned to characteristic spectral regions and chemical shift range. Data are shown as mean \pm standard deviation $(n=3)$

\begin{tabular}{lccr}
\hline Assignments & Chemical shifts (ppm) & C. sorokiniana 21 (\%) & $\begin{array}{l}\text { Monoraphidium } \\
\text { 3s35 (\%) }\end{array}$ \\
\hline $\mathrm{CH}_{3}, \mathrm{CH}_{2}$ & $0-1.6$ & $13.99 \pm 0.23$ & $16.47 \pm 0.49$ \\
$\mathrm{CH}_{2}$, aliphatic $\mathrm{OH}$ & $1.6-2.2$ & $2.51 \pm 0.31$ & $3.43 \pm 0.45$ \\
$\mathrm{CH}_{2} \mathrm{C}=\mathrm{O}, \mathrm{CH}_{3}-\mathrm{Ar},-\mathrm{CH}_{2}-\mathrm{Ar}$ & $2.2-3$ & $14.56 \pm 0.17$ & $10.01 \pm 0.53$ \\
$\mathrm{CH}_{3} \mathrm{O}, \mathrm{CH}_{2} \mathrm{O}, \mathrm{CHO}$ & $3-4.2$ & $60.09 \pm 0.51$ & $38.12 \pm 0.22$ \\
$\mathrm{ArOH}, \mathrm{HC}=\mathrm{C}$ (non-conjugated), $\mathrm{CHO}$ & $4.2-6.4$ & $6.55 \pm 0.42$ & $31.51 \pm 1.02$ \\
$\mathrm{HC}=\mathrm{C}$ (non-conjugated) & $6.4-6.8$ & $0.63 \pm 0.12$ & $0.11 \pm 0.08$ \\
$\mathrm{ArH}, \mathrm{HC}=\mathrm{C}$ (conjugated) & $6.8-8$ & $1.00 \pm 0.11$ & $0.09 \pm 0.06$ \\
$\mathrm{CHO}, \mathrm{COOH}$ & $8-10$ & $0.07 \pm 0.02$ & $0.25 \pm 0.09$ \\
\hline
\end{tabular}




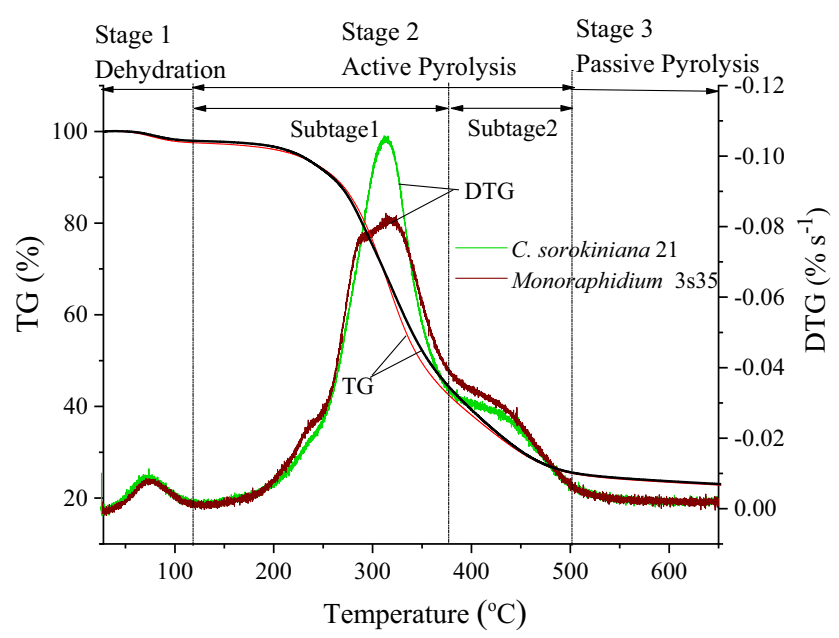

Fig. 2 Thermogravimetry (TG)/derivative thermogravimetry (DTG) diagrams of microalgae Chlorella sorokiniana 21 and Monoraphidium 3s35 residues in a pure nitrogen environment

As shown in Fig. 2, the DTG curve for each microalgal residue had two peaks for the reaction rate $(-\mathrm{dX} / \mathrm{dt})$ of the pyrolysis. It was also observed that the reaction rate of microalgae pyrolysis increased rapidly from 115 to $310{ }^{\circ} \mathrm{C}$ and then dropped dramatically from 310 to $504{ }^{\circ} \mathrm{C}$ with a shoulder from 384 to $445^{\circ} \mathrm{C}$. In substage 1 , the peak of the reaction rate for $C$. sorokiniana $21\left(0.105 \% \mathrm{~s}^{-1}\right)$ was much higher than that for Monoraphidium $3 \mathrm{~s} 35\left(0.0799 \% \mathrm{~s}^{-1}\right)$.

$d^{2} X / d^{2}$ analysis of TG According to Grønli et al. [31], temperatures for the thermal degradation of hemicellulose, cellulose, and lignin could be defined with $\mathrm{d}^{2} \mathrm{X} / \mathrm{d}^{2} \mathrm{t}$ analysis. The $\mathrm{d}^{2} \mathrm{X} / \mathrm{d}^{2} \mathrm{t}$ temperature curves obtained in this study are shown in Fig. 3. As shown in the figure, the characteristics of the thermal decomposition of the microalgal residue can be quantified through the following parameters:

$\mathrm{T}_{\text {onset(hc) }}$ is the extrapolated temperature at the beginning of hemicellulose decomposition;

$\mathrm{T}_{\text {shoulder1 }}$ is the temperature corresponding to the hemicellulose shoulder;

$\mathrm{T}_{\text {peak }}$ is the temperature of the maximum devolatilization rate during the entire pyrolysis;

$\mathrm{T}_{\text {onset (c) }}$ is the extrapolated temperature for the cellulose decomposition;

$\mathrm{T}_{\text {shoulder2 }}$ is the temperature corresponding to the cellulose shoulder and the beginning of the lignin tail in which lignin degradation occurs.

As shown in Fig. 3, the hemicelluloses of the C. sorokiniana 21 and Monoraphidium 3s35 residues started to be thermally decomposed at a $\mathrm{T}_{\text {onset(hc) }}$ of $193{ }^{\circ} \mathrm{C}$ and $191{ }^{\circ} \mathrm{C}$, respectively and reached the maximum reaction rate at a $\mathrm{T}_{\text {peak }}$ of $310^{\circ} \mathrm{C}$ and $311^{\circ} \mathrm{C}$. There was a pyrolysis shoulder observed for the microalgae C. sorokiniana 21 and Monoraphidium $3 \mathrm{~s} 35$ residues at a $\mathrm{T}_{\text {shoulder } 1}$ of $248{ }^{\circ} \mathrm{C}$ and $240{ }^{\circ} \mathrm{C}$, respectively. Although the amount of cellulose in
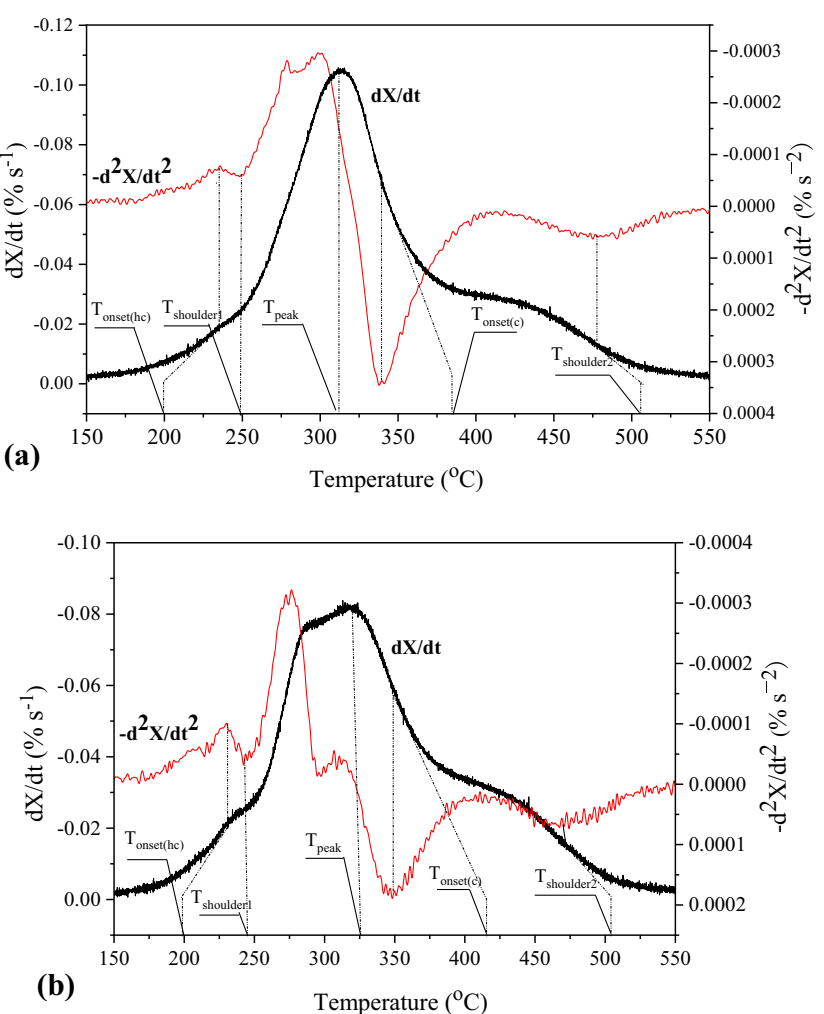

Fig. 3 The first and the second time derivatives of the mass fraction as functions of temperature for the microalgal residues and definitions of the characteristic reaction temperatures. a Chlorella sorokiniana 21. b Monoraphidium 3s35

microalgal residue is much less than that in lignocellulosic biomass, the structure of cellulose is complicated and crystalline [32], compared with that of hemicelluloses. Thus, the pyrolysis stage of cellulose can be observed in Fig. 3. According to this figure, the cellulose of the microalgae C. sorokiniana 21 and Monoraphidium 3s35 residues began thermally decomposing at a $\mathrm{T}_{\text {onset (c) }}$ of $390{ }^{\circ} \mathrm{C}$ and $408{ }^{\circ} \mathrm{C}$, respectively. It has been reported that the weight loss of cellulose during pyrolysis happens at $315-400{ }^{\circ} \mathrm{C}$ [33], which was consistent with our results. The lignin of the microalgae C. sorokiniana 21 and Monoraphidium 3s35 residues began pyrolysis at a $\mathrm{T}_{\text {shoulder } 2}$ of $512{ }^{\circ} \mathrm{C}$ and $504{ }^{\circ} \mathrm{C}$, respectively.

\subsubsection{Microalgae pyrolysis kinetics}

The kinetic parameters for the microalgae pyrolysis in substages 1 and 2 during the active pyrolysis stage are presented in Table 3. As shown in the table, the activation energy of the microalgae pyrolysis in substage $1\left(52.97-58.57 \mathrm{~kJ} \mathrm{~mol}^{-1}\right)$ was much lower than that in substage $2(82.50$ $83.98 \mathrm{~kJ} \mathrm{~mol}^{-1}$ ). It was reported that the peaks of the distribution curve of the activation energy for rice straw, rice husk, corncob, and cellulose were $170,174,183$, and $185 \mathrm{~kJ} \mathrm{~mol}^{-1}$ [34], respectively. It is known that the activation energy represents the potential barrier needed to be overcome in the 
Table 3 Kinetic parameters of the microalgae residue active pyrolysis at the heating rate of $10 \mathrm{k} \mathrm{min}^{-1}$ in the pure nitrogen environment

\begin{tabular}{lcc}
\hline Kinetic parameters & \multicolumn{2}{c}{ Microalgal residues } \\
\cline { 2 - 3 } & C. sorokiniana 21 & Monoraphidium 3s35 \\
\hline Substage $1\left(120{ }^{\circ} \mathrm{C}-380{ }^{\circ} \mathrm{C}\right)$ & \\
$A\left(10^{4} \mathrm{~s}^{-1}\right)$ & 0.95 & 0.04 \\
$E\left(\mathrm{kJmol}^{-1}\right)$ & 52.97 & 58.57 \\
$n$ & 1.46 & 2.21 \\
$R^{2}$ & 0.95 & 0.96 \\
Substage 2 $\left(380{ }^{\circ} \mathrm{C}-500{ }^{\circ} \mathrm{C}\right)$ & \\
$A\left(10^{4} \mathrm{~s}^{-1}\right)$ & 5.15 & 5.94 \\
$E\left(\mathrm{kJmol}^{-1}\right)$ & 82.50 & 83.98 \\
$n$ & 2.34 & 2.24 \\
$R^{2}$ & 0.92 & 0.93 \\
\hline
\end{tabular}

reaction [35]. Compared with lignocellulose biomass, microalgae require less energy to start the thermogravimetric reaction. The results also showed that the activation energy of the residue of $C$. sorokiniana 21 was less than that of Monoraphidium 3s35, indicating that the former is more easily pyrolyzed and has a lower energy barrier.

\subsubsection{Volatile products analysis of TG-FTIR}

To identify the major volatile species and continuously measure the volatiles and the devolatilization temperature during microalgae pyrolysis, TG analysis coupled with FTIR spectroscopy was applied in this study. The TG-FTIR spectra of these two microalgae are shown in Fig. 4. The composition of the volatile products was determined with the characteristic wavenumber bands, while the yield history of the products in the time course was identified by the absorbance against time. An integral form of the Lambert-Beer relation was used for the abovementioned determination and identification [36]. The integrated absorbance (IA, measured in $\mathrm{cm}^{-1}$ ) is the integral value of the spectral absorbance over a selected wavenumber interval characteristic for the compound of interest, which can give a quantitative measure of the gaseous species detected.

During the pyrolysis of microalgal residues, light gases (namely, $\mathrm{C}=\mathrm{O}$ compounds, $\mathrm{CH}_{\mathrm{n}}$ compounds, $\mathrm{CO}_{2}$, and $\mathrm{CO}$ ) were detected in the specific wavenumber intervals listed in Table 4. The results are shown in Fig. 5. Compounds with characteristic carbonyl bonds, typically organic acids, esters, aldehydes, and ketones, are called $\mathrm{C}=\mathrm{O}$ compounds [37]. Compounds with characteristic C-H bonds, typically alkyl, aliphatic, and aromatic compounds, can be classified as $\mathrm{CH}_{n}$ compounds.
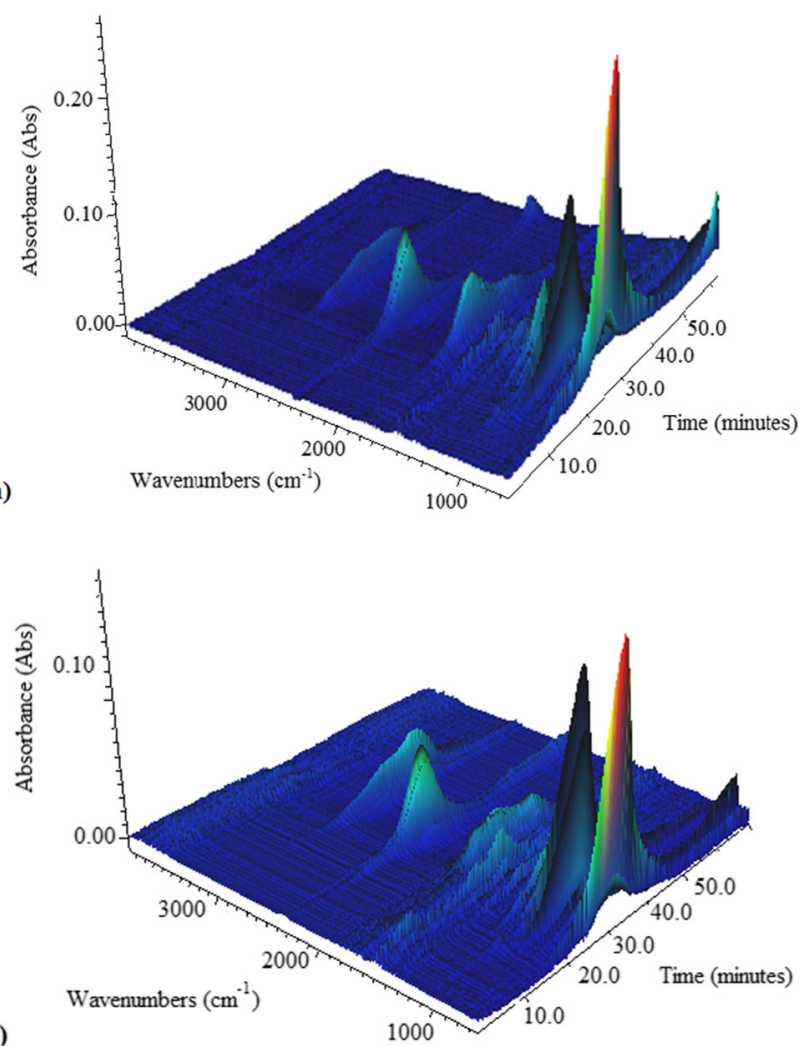

Fig. 4 Three-dimensional spectra of TG-FTIR (thermogravimetric analyzer coupled with fourier transform infrared analysis). a Chlorella sorokiniana 21. (b) Monoraphidium 3s35

$\mathrm{C}=\mathrm{O}$ compounds As shown in Fig. $5 \mathrm{a}$, two peaks were observed for the production of $\mathrm{C}=\mathrm{O}$ compounds $(\mathrm{R}-\mathrm{CHO}$ and $\mathrm{R}-\mathrm{COOH}$ ) during the pyrolysis of both $C$. sorokiniana 21 and Monoraphidium 3s35. According to our results, the temperatures for the maximum production of $\mathrm{C}=\mathrm{O}$ compounds from the pyrolysis of C. sorokiniana 21 and Monoraphidium 3s35 were $251{ }^{\circ} \mathrm{C}$ and $333{ }^{\circ} \mathrm{C}$, respectively. The active pyrolysis temperature for hemicelluloses is usually from 190 to $360^{\circ} \mathrm{C}$. The compositions of hemicellulose in the microalgae C. sorokiniana 21 and Monoraphidium 3s35 were $41.56 \%$ and $42.38 \%$, respectively. The production of the $\mathrm{C}=\mathrm{O}$ compounds is probably due to the pyrolysis of hemicellulose in the microalgae. It was reported that the pyrolysis of Chlorella vulgaris microalgae occurred in the temperature range of

Table 4 Wavenumber intervals of different gaseous species for the definition of the integrated absorbance during the microalgal residue pyrolysis analyzed with TG-FTIR (thermogravimetric analyzer coupled with fourier transform infrared analysis)

\begin{tabular}{ll}
\hline Gas species & Wavenumber interval $\left(\mathrm{cm}^{-1}\right)$ \\
\hline $\mathrm{CH}_{\mathrm{n}}$ group & $2832-3027$ \\
$\mathrm{CO}_{2}$ & $2220-2393$ \\
$\mathrm{CO}$ & $2142-2218$ \\
$\mathrm{C}=\mathrm{O}$ group & $1835-1673$ \\
\hline
\end{tabular}


Fig. 5 Fourier transform infrared (FTIR) integrated absorbance profiles of main gaseous species evolved in the pyrolysis of microalgal residue Chlorella sorokiniana 21 and

Monoraphidium 3s35
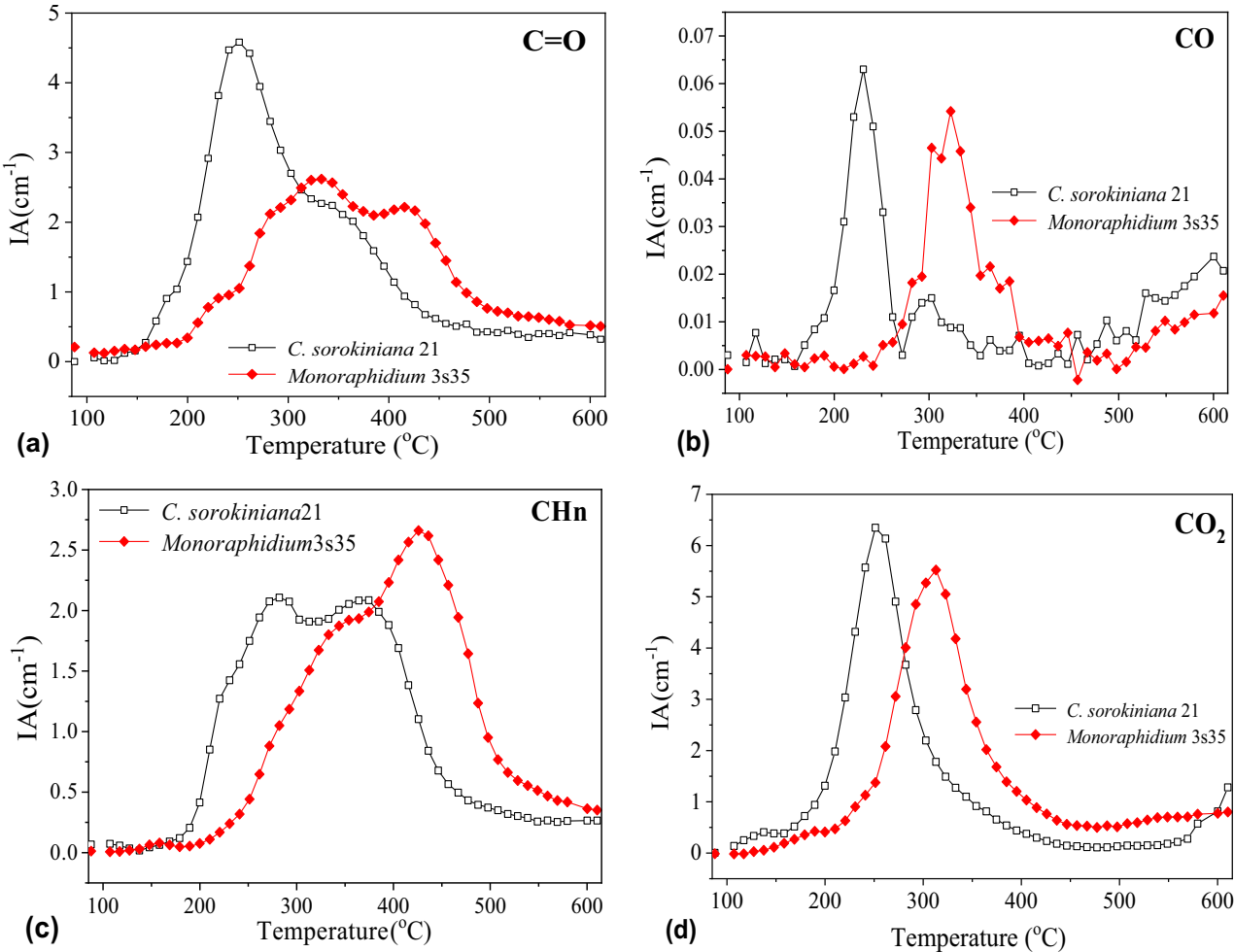

$133-537^{\circ} \mathrm{C}$, and the main weight loss peak occurred at approximately $296{ }^{\circ} \mathrm{C}$, which is consistent with our results. At low temperatures, hemicellulose decomposition contributes to $\mathrm{C}=\mathrm{O}$ and $\mathrm{COOH}$ functional group generation [3]. Hemicelluloses are heterogeneous polymers of pentoses (xylose, arabinose), hexoses (mannose, glucose, galactose), and sugar acids, with a random, amorphous structure. The backbone of hemicellulose consists of O-acetyl, $\alpha-1-$ arabinofuranosyl, $\alpha-1,2$-linked glucuronic, or 4-Omethylglucuronic acid substituents. The release of carbonyl groups can be caused by the cracking of xylan and glucomannan from hemicellulose [4]. Acidic products, especially acetic acid and formic acid, with $\mathrm{C}=\mathrm{O}$ groups, are commonly detected in the bio-oil from the pyrolysis of hemicellulose [5]. The prevalent mechanism of the formation of acetic acid involves a primary elimination reaction of the active $\mathrm{O}$ acetyl groups linked to the main xylan chain at the $\mathrm{C} 2$ position [6].

Carbon monoxide Carbon monoxide (CO) released from pyrolysis of the microalgae is shown in Fig. 5b. The peaks of CO release were observed at $230{ }^{\circ} \mathrm{C}$ and $323{ }^{\circ} \mathrm{C}$ for C. sorokiniana 21 and Monoraphidium 3s35, respectively. C. sorokiniana 21 reached a higher maximum production of $\mathrm{CO}$ at a lower temperature than did Monoraphidium 3s35. Since the release of $\mathrm{CO}$ was mainly caused by the cracking of ether $(\mathrm{C}-\mathrm{O}-\mathrm{C})$ and carboxyl $(\mathrm{C}=\mathrm{O})$ groups [38], the superiority of $C$. sorokiniana 21 in producing $\mathrm{CO}$ might be attributed to the chemical structure difference between these two microalgae. On the other hand, it has been reported that the release of $\mathrm{CO}$ from cellulose was very small, with only a small peak, and that almost no $\mathrm{CO}$ was evolved from lignin pyrolysis at low temperature $\left(<600{ }^{\circ} \mathrm{C}\right)$ [33]. The authors also reported that there was a peak for $\mathrm{CO}$ release from hemicelluloses at $280{ }^{\circ} \mathrm{C}$, which was within the temperature range for $\mathrm{CO}$ release in our observation. Thus, we believe that the $\mathrm{CO}$ production of microalgal residues is mainly from hemicelluloses.

$\mathrm{CH}_{\mathrm{n}}$ compounds The $\mathrm{CH}_{\mathrm{n}}$ compounds released from pyrolysis of the microalgal residues are shown in Fig. 5c. As shown in the figure, the $\mathrm{CH}_{\mathrm{n}}$ compounds showed two main release peaks at $278{ }^{\circ} \mathrm{C}$ and $378{ }^{\circ} \mathrm{C}$ for C. sorokiniana 21 and a shoulder from 322 to $385{ }^{\circ} \mathrm{C}$ for Monoraphidium 3s35. The primary pyrolysis may give rise to the first release peak, while the secondary pyrolysis at a higher temperature might be the driving force for the second release peak of gases, which is in agreement with a report by Yang et al. (2007). The first release peak of $\mathrm{CH}_{\mathrm{n}}$ compounds from C. sorokiniana 21 might be caused by the cracking of the high content of $\mathrm{CH}_{3} \mathrm{O}$ compounds as shown in Table 2 . The cracking procedure mainly happened during primary pyrolysis at low temperature. For Monoraphidium 3s35, the production of $\mathrm{CH}_{\mathrm{n}}$ compounds might be due to secondary pyrolysis. It was reported that 1,4-anhydro-d-xylopyranose is one of the main condensable products from hemicellulose pyrolysis, which is attributed to cleavage of the glycosidic linkage of the xylan chain, followed by rearrangement of the depolymerized molecules. Studies 
have inferred that most of the produced 1,4-anhydro-dxylopyranose would be instantly consumed to produce twocarbon and three-carbon fragments as well as gases including $\mathrm{CH}_{4}$, acting as an intermediate product from the pyrolysis of hemicellulose [5].

Carbon dioxide Carbon dioxide $\left(\mathrm{CO}_{2}\right)$ released from pyrolysis of the microalgae is shown in Fig. 5d. As shown in the figure, $\mathrm{CO}_{2}$ generation reached a peak at $250{ }^{\circ} \mathrm{C}$ and $313{ }^{\circ} \mathrm{C}$ for C. sorokiniana 21 and Monoraphidium 3s35, respectively. Based on the results, Monoraphidium 3s35 produced less $\mathrm{CO}_{2}$ than $C$. sorokiniana 21 during pyrolysis. The production of $\mathrm{CO}_{2}$ is due to the cracking and scission of $\mathrm{C}-\mathrm{C}$ and $\mathrm{C}-\mathrm{O}$ bonds during pyrolysis [39].

\section{Conclusion}

The present study showed that microalgal residues have clear advantages over plant lignocellulosic materials in terms of pyrolysis, with a lower activation energy (52.97$\left.83.98 \mathrm{~kJ} \mathrm{~mol}^{-1}\right)$ and lower final residue yields $(22.20$ $22.75 \%)$. Due to the high content of hemicellulose (41.56$42.38 \%$ ) and the predominant structure of carboxyl and carbonyl functional groups, the main evolution products were $\mathrm{C}=\mathrm{O}$ and $\mathrm{CH}_{\mathrm{n}}$ compounds, presenting great potential as syngas. Moreover, the chemical structure differences between C. sorokiniana 21 and Monoraphidium 3s35 probably resulted in the observed variation in the pyrolysis characteristics and production of volatiles.

Authors' contributions Details of the individual author's contribution towards the manuscript have been illustrated below:

Professor Shuangfei $\mathrm{Li}$, as the first author, collected, processed and analyzed the data. He was also responsible for all drafts of the manuscript.

Professor Xuewei Yang, as the corresponding author, was responsible for the conceptualization of the study, design and planning of the manuscript, as well as the analysis and interpretation of the results.

Dr. Liangxu Liu, as the coauthor, was responsible for analyzing the data and improving the figure quality, English writing and discussion section of the manuscript.

Professor Jay Jiayang Cheng, as the coauthor, was responsible for critical reading and finalization of the manuscript.

Funding information This project was partially supported by the development special funds of Shenzhen Strategic Emerging Industries and Future Industries (Grant No. KJYY20180201180253571), Shenzhen Science and Technology Innovation Shenzhen-Hong Kong Joint Research Project (Grant No. SGLH20180622152010394), and Shenzhen Overseas High-level Talent Innovation and Entrepreneurship Special Fund Project (Grant No. KQJSCX20180328093806045).

\section{Compliance with ethical standards}

Conflict of interest The authors declare that they have no conflict of interest.
Statement of informed consent Not applicable.

Open Access This article is licensed under a Creative Commons Attribution 4.0 International License, which permits use, sharing, adaptation, distribution and reproduction in any medium or format, as long as you give appropriate credit to the original author(s) and the source, provide a link to the Creative Commons licence, and indicate if changes were made. The images or other third party material in this article are included in the article's Creative Commons licence, unless indicated otherwise in a credit line to the material. If material is not included in the article's Creative Commons licence and your intended use is not permitted by statutory regulation or exceeds the permitted use, you will need to obtain permission directly from the copyright holder. To view a copy of this licence, visit http://creativecommons.org/licenses/by/4.0/.

\section{References}

1. Field CB, Campbell JE, Lobell DB (2008) Biomass energy: the scale of the potential resource. Trends Ecol Evol 23(2):65-72

2. Chisti Y (2007) Biodiesel from microalgae. Biotechnol Adv 25(3): 294-306

3. Clarens AF, Resurreccion EP, White MA, Colosi LM (2010) Environmental life cycle comparison of algae to other bioenergy feedstocks. Environmental Science \& Technology 44(5):18131819

4. Callegari A, Bolognesi S, Cecconet D, Capodaglio AG (2019) Production technologies, current role, and future prospects of biofuels feedstocks: a state-of-the-art review. Crit Rev Environ Sci Technol:1-53

5. Mohan D, Pittman CU, Steele PH (2006) Pyrolysis of wood/ biomass for bio-oil: a critical review. Energy Fuel 20(3):848-889

6. Kara B, Emir Z, Kaygusuz K (2012) Thermal processing technologies for biomass conversion to energy. Journal of Engineering Research and Applied Science 1(1):55-62

7. Yang X, Zhang R, Fu J, Geng S, Cheng JJ, Sun Y (2014) Pyrolysis kinetic and product analysis of different microalgal biomass by distributed activation energy model and pyrolysis-gas chromatography-mass spectrometry. Bioresour Technol 163:335-342

8. Chen W-H, Chu Y-S, Liu J-L, Chang J-S (2018) Thermal degradation of carbohydrates, proteins and lipids in microalgae analyzed by evolutionary computation. Energy Convers Manag 160:209-219

9. Ghosh A, Khanra S, Mondal M, Halder G, Tiwari O, Saini S, Bhowmick TK, Gayen K (2016) Progress toward isolation of strains and genetically engineered strains of microalgae for production of biofuel and other value added chemicals: a review. Energy Convers Manag 113:104-118

10. Pielichowski K, Njuguna J (2005) Thermal degradation of polymeric materials. Smithers Rapra Technology,

11. Marcilla A, Gómez-Siurana A, Gomis C, Chápuli E, Catalá MC, Valdés FJ (2009) Characterization of microalgal species through TGA/FTIR analysis: application to $<\mathrm{i}>$ nannochloropsis $</ \mathrm{i}>\mathrm{sp}$. Thermochim Acta 484(1):41-47

12. Allen MM (1968) Simple conditions for growth of unicellular bluegreen algae on plates1, 2. J Phycol 4(1):1-4

13. Williams S (1984) Official methods of analysis of the Association of Official Analytical Chemists vol Ed 14

14. Aguilera-Morales M, Casas-Valdez M, Carrillo-Domınguez S, González-Acosta B, Pérez-Gil F (2005) Chemical composition and microbiological assays of marine algae $<\mathrm{i}>$ Enteromorpha $</$ i> spp. as a potential food source. J Food Compos Anal 18(1): 79-88

15. Franklin ST, Martin KR, Baer RJ, Schingoethe DJ, Hippen AR (1999) Dietary marine algae (Schizochytrium sp.) increases 
concentrations of conjugated linoleic, docosahexaenoic and transvaccenic acids in milk of dairy cows. J Nutr 129(11):20482054

16. Vardon DR, Sharma B, Scott J, Yu G, Wang Z, Schideman L, Zhang Y, Strathmann TJ (2011) Chemical properties of biocrude oil from the hydrothermal liquefaction of $<\mathrm{i}>$ Spirulina $</ \mathrm{i}>$ algae, swine manure, and digested anaerobic sludge. Bioresour Technol 102(17):8295-8303

17. Rebolloso Fuentes M, Acién Fernández G, Sánchez Pérez J, Guil Guerrero J (2000) Biomass nutrient profiles of the microalga $<\mathrm{i}>$ Porphyridium cruentum</i $>$. Food Chem 70(3):345-353

18. Pv VS, Robertson J, Lewis B (1991) Methods for dietary fiber, neutral detergent fiber, and nonstarch polysaccharides in relation to animal nutrition. J Dairy Sci 74(10):3583-3597

19. Cochran R, Adams D, Wallace J, Galyean M (1986) Predicting digestibility of different diets with internal markers: evaluation of four potential markers. J Anim Sci 63(5):1476-1483

20. Hatfield RD, Jung HJG, Ralph J, Buxton DR, Weimer PJ (1994) A comparison of the insoluble residues produced by the Klason lignin and acid detergent lignin procedures. J Sci Food Agric 65(1):51-58

21. Dien BS, Jung HJG, Vogel KP, Casler MD, Lamb JAFS, Iten L, Mitchell RB, Sarath G (2006) Chemical composition and response to dilute-acid pretreatment and enzymatic saccharification of alfalfa, reed canarygrass, and switchgrass. Biomass Bioenergy 30(10): $880-891$

22. Zhou D, Zhang L, Zhang S, Fu H, Chen J (2010) Hydrothermal liquefaction of macroalgae Enteromorpha prolifera to bio-oil. Energy Fuel 24(7):4054-4061

23. Almeida JR, Modig T, Petersson A, Hähn-Hägerdal B, Lidén G, Gorwa-Grauslund MF (2007) Increased tolerance and conversion of inhibitors in lignocellulosic hydrolysates by Saccharomyces cerevisiae. J Chem Technol Biotechnol 82(4):340-349

24. Okuda K, Oka K, Onda A, Kajiyoshi K, Hiraoka M, Yanagisawa K (2008) Hydrothermal fractional pretreatment of sea algae and its enhanced enzymatic hydrolysis. J Chem Technol Biotechnol 83(6):836-841

25. Martone PT, Estevez JM, Lu F, Ruel K, Denny MW, Somerville C, Ralph J (2009) Discovery of lignin in seaweed reveals convergent evolution of cell-wall architecture. Curr Biol 19(2):169-175

26. Delwiche CF, Graham LE, Thomson N (1989) Lignin-like compounds and sporopollenin in coleochaete, an algal model for land plant ancestry. Science 245(4916):399-401
27. Moon RJ, Martini A, Nairn J, Simonsen J, Youngblood J (2011) Cellulose nanomaterials review: structure, properties and nanocomposites. Chem Soc Rev 40(7):3941-3994

28. Yang X, Zeng Y, Ma F, Zhang X, Yu H (2010) Effect of biopretreatment on thermogravimetric and chemical characteristics of corn stover by different white-rot fungi. Bioresour Technol 101(14):5475-5479

29. Shen D, Gu S, Bridgwater AV (2010) Study on the pyrolytic behaviour of xylan-based hemicellulose using TG-FTIR and Py-GCFTIR. J Anal Appl Pyrolysis 87(2):199-206

30. Chen G, Leung D (2003) Experimental investigation of biomass waste, (rice straw, cotton stalk, and pine sawdust), pyrolysis characteristics. Energy Sources 25(4):331-337

31. Grønli MG, Várhegyi G, Di Blasi C (2002) Thermogravimetric analysis and devolatilization kinetics of wood. Ind Eng Chem Res 41(17):4201-4208

32. Sugiyama J, Vuong R, Chanzy H (1991) Electron diffraction study on the two crystalline phases occurring in native cellulose from an algal cell wall. Macromolecules 24(14):4168-4175

33. Yang H, Yan R, Chen H, Lee DH, Zheng C (2007) Characteristics of hemicellulose, cellulose and lignin pyrolysis. Fuel 86(12-13): $1781-1788$

34. Sonobe T, Worasuwannarak N (2008) Kinetic analyses of biomass pyrolysis using the distributed activation energy model. Fuel 87(3): 414-421

35. Balooch M, Cardillo M, Miller D, Stickney R (1974) Molecular beam study of the apparent activation barrier associated with adsorption and desorption of hydrogen on copper. Surf Sci 46(2):358 392

36. Marsanich K, Barontini F, Cozzani V, Petarca L (2002) Advanced pulse calibration techniques for the quantitative analysis of TGFTIR data. Thermochim Acta 390(1):153-168

37. Biagini E, Barontini F, Tognotti L (2006) Devolatilization of biomass fuels and biomass components studied by TG/FTIR technique. Ind Eng Chem Res 45(13):4486-4493

38. Lv G, Wu S, Lou R, Yang Q (2010) Analytical pyrolysis characteristics of enzymatic/mild acidolysis lignin from sugarcane bagasse. Cellulose Chemistry \& Technology 44(9):335

39. Peng Y, Wu S (2011) Fast pyrolysis characteristics of sugarcane bagasse hemicellulose. Cellul Chem Technol 45(9):605

Publisher's Note Springer Nature remains neutral with regard to jurisdictional claims in published maps and institutional affiliations. 